\title{
The Effects of Reciprocal Teaching on Reading Comprehension of Iranian EFL Learners
}

Leila Ashegh Navaie*

Khatam University, Tehran, Iran

Corresponding Author: Leila Ashegh Navaie, E-mail: lasheghnavaie@gmail.com

\section{ARTICLE INFO}

Article history

Received: March 03, 2018

Accepted: May 14, 2018

Published: August 31, 2018

Volume: 9 Issue: 4

Advance access: July 2018

Conflicts of interest: None

Funding: None

\begin{abstract}
The present study aimed at investigating the effectiveness of the Reciprocal Teaching Procedure (RTP) on reading comprehension of intermediate Iranian EFL learners in Iran. Two intact groups were chosen non-randomly, one as the control group and the other as the experimental group. Then an IELTS reading test was administered to both groups as pretest. After analyzing the collected scores by independent t-test it was known that there was no meaningful difference between control and experimental groups before the treatment. Both groups were offered 15 sessions of reading, the experimental group received treatment, they were taught reading by applying RTP as an instructional strategy, but the control group was taught reading through the conventional method. The results showed that reciprocal teaching can improve reading comprehension of Iranian EFL learners. Pedagogical implications are discussed.
\end{abstract}

Key words:

Reciprocal Teaching Procedure,

Reading Comprehension,

Instructional Strategy,

English As A Foreign Language (EFL)

The role of reading in success of the language learners and students is undeniable. Rivers (1981) finds reading a plausible activity and a significant source of input in classes. In the same line, Chastain (1988) regards reading a suitable source to give large amounts of data to learners.

The exploratory studies conducted on reading problems of second and foreign language learners in different contexts has revealed that mastering the reading skill has been a cumbersome issue in some contexts. In Iran, for example, conventional teaching of English reading is based on translation of the text. Atai and Nazari (2014) note that Iranian English language learners translate the texts to understand the text. This habit has still remained in most reading comprehension practices, though, professionally, it is neither admired nor advised. Due to being time consuming, applying this old method would lead to learners' failure in most summative exams or reading comprehension tests; thus, this poor performance might lead to students' frustration and anxiety over learning English.

Shorey and Mohktari (2001 as cited in Pammu et al., 2014) confirm that in order to improve reading comprehension of the learners educators need to enhance the learners' reading strategies. In addition, Pammu, Amir, and Maasum (2014) state that foreign language learners find it difficult and challenging to deal with reading comprehension compared to native language learners due to the culturally specific mental processes involved in reading. In terms of strategy, Küçükoğlu (2013) states that active involvement and autonomy should be targeted as features of good reading strategies. Considering such features, the researcher was motivated to find the effect of reciprocal teaching on reading comprehension of Iranian EFL learners.

\section{Research Question}

What is the effect of reciprocal teaching on reading comprehension of intermediate Iranian EFL learners?

\section{REVIEW OF THE RELATED LITERATURE}

\section{Reciprocal Teaching Procedure (RTP)}

RTP is an explicit instructional strategy for teaching reading which was designed and developed by Palincsar and Brown (1984); they conducted two instructional studies with the aim of finding the result of "comprehension-fostering and comprehension-monitoring activities of poor comprehenders" (Palincsar and Brown, 1984). Their instruction included four steps: summarizing (self-review), questioning, clarifying, and predicting; and their method was reciprocal in which students and teacher took turns "leading a dialogue". 
Comparing two groups in Study 1, in which experimental group was taught by reciprocal teaching and control group was taught by typical method led to significant improvement in students' text comprehension, applying other skills and procedures effectively such as giving summaries and generating questions, and mainly improvement in standardized comprehension scores. Many of the results of study 1 which was conducted by an experimenter were replicated in Study 2 in which volunteer teachers (a "real" teacher, not an investigator) carried out the experiment with their existing reading groups, it took place in "naturally occurring groups within school settings" (Palincsar and Brown,1984).

Reciprocal teaching (RT) as an instructional procedure can be used 'to improve students' text comprehension skills through scaffolded instruction of four comprehension-fostering and comprehension-monitoring strategies (Palincsar \& Brown, 1984; Palincsar, David \& Brown, 1989; Rosenshine \& Meister, 1994), that is, (a) generating one's own questions, (b) summarizing parts of the text, (c) clarifying word meanings and confusing text passages, and (d) predicting what might come next in the text'(cited in Sporer, Brunstein, and Kieschke, 2009).

A substantial body of research has been done to define reciprocal teaching (RT) and report the positive effects of it; Palincsar, Brown, and Campione (1989; cited in Foster and Rotoloni, 2005) define reciprocal teaching as a dialogue between teacher and student. This dialogue is described as reciprocal because each learner acts in response to another. This interaction may occur between teacher and students or between students themselves. "It incorporates four activities: summarizing, questioning, clarifying, and predicting (Oczkus, 2003; Palincsar \& Brown, 1984) in which students move from spectators to performers" (cited in Ghorbani, Gangeraj, \& Zahed Alavi, 2013). According to Allen (2003) "the teacher collaborates with the students and hands over the control of the group to the students in the end" (cited in Ghorbani, et al., 2013). Sporer also described this dialogue as a going activity between students and a "dialogue leader" who can be either a teacher or a student; the leader "provides conditional knowledge about strategy use, and helps students to apply a strategy to a passage"; after students' familiarity "with the strategies and the procedure, dialogue leaders fade their involvement and other students take turns as discussion leaders" (Sporer et al., 2009).

In reciprocal teaching "reading comprehension is viewed as a problem-solving activity in which thinking is promoted while reading" (cited in Glaser, 1990). The technique is a group-problem activity in which students read a passage of text, paragraph by paragraph; During the reading students apply four activities recommended by Palincsar and Brown (1984) to improve comprehension: (a) summarizing the main points and monitoring understanding of the text; (b) predicting what might come next; (c) clarifying unclear or ambiguous words, phrases, or sentences; and (d) generating questions and answering them (Palincsar \& Brown, 1984; Brown \& Palincsar,1989 cited in Hou,2015). During the early stages of reciprocal teaching, the instructor assumes the major responsibility for instruction by explicitly modeling the four strategies. The researcher(dialogue leader) taught and modeled the predicting, questioning, clarifying, and summarizing strategies explicitly as a way to improve the students' comprehension skills (Ghorbani et al., 2013). After modeling in the initial phase, students take turns leading the group dialogue and practice the strategies on other sections of text. At that stage, the teacher becomes a mediator who provides guidance and feedback (Brown \& Palincsar, 1989). The teacher gradually fades modeling of the strategies which s/ he provided as scaffold instruction (Hacker \& Tenent, 2002; Palincsar \& Brown, 1984 cited in Sporer et al., 2009). Eventually, the students undertake and share most of the responsibilities and thinking; it is confirmed by what Palinscar and Brown (1984) reported of their study:

\section{METHOD}

\section{Participants}

The participants of this study were 76 male and female students of English language Institute in Amol. Their age ranged from 18 to 35 . They were chosen from all the available intermediate students at Simin Institute as well as Shomal Institute. The reason behind choosing these students was their background knowledge, their exposure to English as a foreign language and their reading comprehension practice. The intact groups were used; the students were divided into two groups of 38. Randomly, one group was selected as the control group and the other as the experimental group. In other words, 38 students were assigned to the experimental, or reciprocal teaching group and 38 students to the control, or non-reciprocal group.

\section{Procedure and Design}

This is a quasi-experimental research using intact groups, involving pretest-posttest measurements. The pretest and posttest which were two different versions of IELTS test. The design allows us to examine the effects of reciprocal teaching on EFL learners' reading comprehension. After students were selected they were randomly divided in to two equal groups, one as experimental and one as control group. The study was run in three phases. In the first phase, all subjects in all classes were given the pre-test in order to recognize the students' reading comprehension ability before the treatment. The time given was 1 hour. In the second phase, subjects in the reciprocal teaching groups had explicit reciprocal teaching instruction. Subjects in the non-reciprocal teaching groups used a more traditional approach modeled on the same activity. All instruction in both groups lasted for 15 sessions and an hour per session. Before starting to work with reciprocal teaching method, students in experimental group had one introduction session to become familiarized with reciprocal teaching, its goals, procedures, and advantages.

\section{Treatment}

The researcher administered all treatments. She had a briefing session with teacher in control group. Although the re- 
searcher was familiar with the traditional method used in the institute she made sure the teacher in control group did not follow the reciprocal teaching method and she observed the teacher in control group regularly. While the nature and procedures of reciprocal teaching was explained to the students in the first session as introduction session, during the early stages of implementing this method the teacher explained it again very shortly then selects a section of the text and read aloud that section. After reading a section of text the teacher began to model the reciprocal teaching process by generating and asking a question. The teacher might ask several questions before summarizing the section of text that was read. Following the summarization process, the teacher clarified any difficult expression, vocabulary, or structure within the text. Finally, through the use of text-based cues, the teacher predicted about the next section of text. This cycle of questioning, summarizing, clarifying, and predicting that can be used in any order continue until the students begin to understand the processes themselves. Gradually the teacher began to transfer control of the process to the students by having the students adopt the role of discussion leader. These leaders then initiate this dialogical process, while the teacher assumes the role of observer and facilitator. "As the students gain confidence and competence with the strategies, they take over the teaching role and model the strategy use for their peers" (Richek, Caldwell, Jennings, \& lerner, 2002). The culmination point was that one student asked question and others provided answers and comments, one student summarized and others provided elaborations and simplifications, one student identified difficult passages, terminologies or concepts and others clarified, and one student predicted the upcoming text and others refined and provided alternative hypotheses.

Subjects in the non-reciprocal teaching group, control group, used a more traditional approach on the same activity. The students in this group also read 10 reading texts from the same books as the reciprocal teaching group but without receiving any treatment.

\section{Data Analysis}

The distribution of the scores was checked prior to the main study for all test. It was found that ratios of skewness and kurtosis fall within the range of $+/-1$; thus, normal distribution of scores. In addition the reliability of the scores was checked. As Cronbach $\alpha$ was.081 and.79 respectively, it can be concluded that both pretest and posttest scores were reliable.

\section{The Pretest}

In order to make sure the difference between the reading comprehensions of both groups prior to the main study was negligible, independent samples t-test was run.

The results of independent samples t-test $(\mathrm{t}(74)=.14$, $\mathrm{Sig}=.887$ ) indicates that the difference between the control group and the experimental group on the pretest pf reading is not significant.

\section{The Research Question}

In order to find out whether the difference between the experimental group and the control group on posttest of reading is significant, independent samples t-test was run.

The results of independent samples t-test $(\mathrm{t}(74)=2.04$, $\mathrm{Sig}=.001)$ shows that the difference between the groups is significant; thus, it can be concluded that reciprocal teaching affects reading comprehension of Iranian EFL learners.

\section{DISCUSSION AND CONCLUSION}

The result of t-test illustrates there is a significant difference between reciprocal and non-reciprocal groups. These results reject the null hypothesis and confirm the effect of reciprocal teaching on the EFL learners' reading comprehension performance. After administering and scoring pre-test, it was found that participants in both experimental and control group didn't perform well on reading comprehension test; the scores were mostly low. According to the results of scores and also students' complaining during exam about comprehension test, it can be concluded that students were not familiar with the type of reading comprehension test. Of course both groups performed equally. After scoring the post-test and producing statistical analyses it can be concluded that reciprocal teaching is meaningful and useful; it is more effective than traditional method in teaching reading skill. It means that reciprocal teaching could improve

Table 1. Independent samples t-test, pretest of scores

\begin{tabular}{llllllll}
\hline & N & Mean & SD & MD & T & df & Sig \\
\hline Experimental & 38 & 21.71 & 3.56 & -0.105 & 0.14 & 74 & 0.887 \\
Control & 38 & 21.81 & 2.85 & & & & \\
\hline$P<.05$ & & & & & &
\end{tabular}

Table 2. Independent samples t-test; posttest of reading

\begin{tabular}{lccccccc}
\hline & N & Mean & SD & MD & t & df & Sig \\
\hline Experimental & 38 & 23.21 & 3.87 & 2.79 & 2.04 & 74 & 0.001 \\
Control & 38 & 20.42 & 3.73 & & & & \\
\hline
\end{tabular}


reading comprehension performance of EFL intermediate learners in Iran.

The findings of this study can be compared or contrasted with those of other researchers. In reporting the result of Study 1, Palinscar and Brown (1984) stated that in addition to the increases on the daily comprehension measures, five of the six students improved their classroom comprehension scores from 20\% to 60\% correct, (Palinscar \& Brown, 1984); they also confirmed that "the students improved dramatically on their daily assessment passages"(p.156). In addition, it is matched to what Hou(2015)found in his study," he conducted a study to discover the effects of reciprocal teaching (RT) on metacognitive awareness and reading comprehension of Taiwanese junior college students". The results showed statistically to have a significant impact on enhancing students' reading scores (Hou, 2015). On the other hand, it is in contrast with what Fung, Wilkinson, Moore (2003) in their study concluded; they stated that reciprocal teaching has been used with ESL students but with mixed success.

Since students' active participation is a key component of reciprocal teaching and on the other hand this essential factor is mostly absent in foreign language learning environment in Iran, the reactions of participants in this study were quite rewarding. It was not expected that students' achievement during short time of treatment would be remarkable whereas they responded so well to this method in a 10 session period. Some of the students even evolved and demonstrated a talent for making predictions, creating meaningful questions and leading the discussions. Of course in case of generating questions most of the students ask direct or literal questions rather than inference or tricky questions. They enjoyed discussing with each other and correcting each other's mistakes. They also enjoyed playing the role of leader or teacher. This gave them confidence and more motivation for being an active and independent reader; and it is also in consistent with Richek, Caldwell, Jennings, \& Lerner's findings (2002), "they concluded that as the students gain confidence and competence with the strategies, they take over the teaching role and model the strategy use for their peers". Another valuable point of this study was that students constructed their own understanding of the text as the teacher guided them to acquire and master the tools or strategies with which to comprehend it, and it is in accordance with what is expected from students in reciprocal teaching.

An important finding that emerged from this study is that while students tried to give a good summary they mostly failed; we think they need help in this case; it is also incongruent with what Seymour and Osana (2003) concluded, they said that "students may understand a paragraph but still not be able to summarize it". Moreover, if reciprocal teaching has applied in a learning environment but students don't have satisfying performance on the reading comprehension test, it doesn't mean they are not successful in implementing this strategy but failure may be due to other factors such as students may not be familiar with the kind of test, reading comprehension test as it was proved in the pretest phase of this study, another factor is teacher's mastery in performing this method in the class; how well teacher models reciprocal teaching and scaffolds is very important.

What we want to emphasize in this study is the importance of cooperation, peer correction, and group working in learning. Group working is significant with changing the world toward a highly technological village and a united land in which people try to resemble each other by immersing in different cultures in order to live with democracy and peace. As far as no absolute system can survive and be productive, no educational one-way system in which teachers or educational administrative are the only power can continue to exist. I believe that with achievements in reciprocal teaching great evolution would happen in education especially in EFL or ESL learning environment because in reciprocal teaching teachers and students are held mutually responsible and accountable for teaching and learning in the setting.

With regard to teaching, the findings may be useful for teachers, teacher trainers, and students at any level in universities, schools or private foreign language institutes. Teachers can apply a very different method in teaching reading; teachers of university can also utilize this method in teaching, especially in teaching reading text to students whose major is English, they can provide students with necessary supplementary and remedial tasks and programs to improve their reading ability. Additionally, they should go far beyond that and make the learners familiar with varieties of techniques with which they can read a text comprehensively. The findings may encourage teachers who still believe in teacher-centeredness in language teaching to change their viewpoints in favor of more learner-centered approaches; teachers implementing this method should pay close attention to students' participation levels. With applying reciprocal teaching, students can use an interesting and active method which is combined of different strategies instead of confining themselves to use separate strategies one by one. Teacher trainers should train teachers to implement this strategy appropriately and to consider all requirements for applying it.

There are some limitations in this study; it was performed in intermediate level, so other proficiency levels such as elementary or advanced level were not investigated; next, the research was done in the foreign language institutes, therefore other settings were not regarded.

Further research studies can be conducted to investigate the effect of reciprocal teaching on other students with primary and advanced level of proficiency. It also can be investigated in other settings like public schools or universities; moreover the effect of reciprocal teaching on the improvement of other skills (listening, speaking or writing) can also be examined for further research studies.

\section{REFERENCES}

Anderson, N.J. (2007). Active skills for reading: Book 2 ( $2^{\text {nd }}$ ed. $)$. Thomson ELT.

Atai, M. R., \& Nazari, O. (2011). Exploring reading comprehension needs of Iranian EAP students of health information management (HIM): A triangulated approach. System, 39(1), 30-43. 
Brown, A.L. \& Palinscar, A.S. (1989). Guided cooperative learning and individual knowledge acquisition. In L.B. RESNICK (Ed.) Knowing, Learning and Instruction: essays in honour of Robert Glaser. (pp. 393-451). Hillsdale, NJ: Erlbaum.

Chastain, K. (1988). Developing second-language skills, theory and practice ( $3^{\text {rd }}$ ed.). New York: Harcourt Brace Jovanovich.

Foster, E., \& Rotoloni, B. (2005). Reciprocal teaching: General overview of theories. In M. Orey (Ed.), Emerging perspectives on learning, teaching, and technology. Retrieved January, 2008, from http://projects.coe.uga.edu/epltt/.

Fung, I.Y.Y., Wilkinson, I.A.G., \& Moore, D.W. (2003). L1 assisted reciprocal teaching to improve ESL students' comprehension of English expository text. Learning and Instruction, 13, 1-31.

Ghorbani, M.R., Ardeshir Gangeraj, A., \& Zahed Alavi, S. (2013). Reciprocal teaching of comprehension strategies improves EFL learners' writing ability. Current Issues in Education. 16,1.

Hou, Y.J., (2015). Reciprocal teaching, metacognitive awareness, and academic performance in Taiwanese junior college students. International Journal of Teaching and Education, III(4), 15-32.

Küçükoğlu, H. (2013). Improving reading skills through effective reading Strategies. Procedia - Social and Behavioral Sciences, 70,709-714.
Oczkus, L. (2003). Reciprocal teaching at work: Strategies for improving reading comprehension. Newark, DE: International reading association.

Padma, B. (2008). Reciprocal Teaching techniques, New Delhi, APH.

Paliscsar, A. S., \& Brown, A. L. (1984). Reciprocal Teaching of comprehension - fostering \& comprehension-monitoring activities. Cognition \& Instruction, 1(2), 117-172.

Pammu, A., Amir, Z., \& Maasum, T. (2014). Metacognitive Reading Strategies of Less Proficient Tertiary Learners: A Case Study of EFL Learners at a Public University in Makassar, Indonesia. Procedia - Social and Behavioral Sciences, 118-358.

Richards, J.C., (2005). Interchange (3 ${ }^{\text {rd }}$ ed.). Cambridge University Press.

Rivers, W.M., (1981). Teaching foreign-language skill. Chicago: University of Chicago Press.

Seymour, J. R., \& Osana, H. P. (2003). Reciprocal Teaching procedures and principles: two teachers' developing understanding. Teaching and Teacher Education, 19, 325-344.

Sporer, N., Brunstein, J.C., \& Kieschke, U. (2008). Improving students' reading comprehension skills: Effects of strategy instruction and reciprocal teaching, Learning and Instruction, 19 (3), 272-286 